The Price of Poverty 
This page intentionally left blank 


\section{The Price of Poverty}

Money, Work, and Culture

in the Mexican American Barrio

Daniel Dohan 
Excerpts from Let Us Now Praise Famous Men (C) I939, I940 by James Agee and Walker Evans. Copyright () renewed 1969 by Mia Fritsch Agee and Walker Evans. Reprinted by permission of Houghton Mifflin Company. All rights reserved.

University of California Press

Berkeley and Los Angeles, California

University of California Press, Ltd.

London, England

(C) 2003 by the Regents of the University of California

Library of Congress Cataloging-in-Publication Data

Dohan, Daniel, I965-.

The price of poverty : money, work, and culture in the Mexican American barrio / Daniel Dohan.

p. $\mathrm{cm}$.

Includes bibliographical references and index.

ISBN 0-520-22756-5 (cloth : alk. paper)ISBN 0-520-23889-3 (pbk. : alk. paper)

I. Mexican Americans - California - San JoseEconomic conditions. 2. Mexican AmericansCalifornia-East Los Angeles-Economic conditions. 3. Urban poor-California-San Jose. 4. Urban poor-California-East Los Angeles. 5. San Jose (Calif.)-Economic conditions. 6. East Los Angeles (Calif.) -Economic conditions. 7. San Jose (Calif.) Ethnic relations. 8. East Los Angeles (Calif.) - Ethnic relations. 9. Hispanic American neighborhoodsCalifornia-Case studies. I. Title.

F869.S394 D64 2003

$330.9794^{\prime} 74^{\prime} 00896872-\mathrm{dc} 2 \mathrm{I}$

2003002460

Manufactured in the United States of America
I 2 II IO O
0807
0605
0403
IO $\begin{array}{lllllllll}9 & 8 & 7 & 6 & 5 & 4 & 3 & 2 & \text { I }\end{array}$

The paper used in this publication is both acid-free and totally chlorine-free (TCF). It meets the minimum requirements of ANSI/NISO Z39.48-I992 (R I997) (Permanence of Paper). @) 